\title{
UNROOFING TECHNIQUE AS AN OPTION FOR THE ENDOSCOPIC TREATMENT OF GIANT GASTROINTESTINAL LIPOMAS
}

\begin{abstract}
Marcela Kopáčová, Stanislav Rejchrt, Jan Bureš
2nd Department of Internal Medicine - Gastroenterology, Charles University in Prague, Faculty of Medicine in Hradec Králové, University Hospital Hradec Králové, Czech Republic

Summary: Gastrointestinal lipomas are usually asymptomatic, detected incidentally. However, they can cause severe symptoms such as obstruction, invagination, and bleeding. The transsection of an infarcted or large lipoma by needle sphincterotome (needle knife) and/or snare polypectomy of the upper part of the tumour is an option for the endoscopy treatment of giant infarcted lipomas. Cutting a top of lipoma (unroofing technique) allowed flow out of adipose tissue from the lipoma.
\end{abstract}

Keywords: Endoscopy; Giant gastrointestinal lipoma; Needle sphicterotome; Unroofing technique

\section{Introduction}

Gastrointestinal lipomas are rare, benign, usually single, slowly growing mesenchymal tumours, mostly found in the colon $(65 \%)$ and small bowel $(20 \%)(1-6)$. Lipomas tend to occur in older population sections and they are usually asymptomatic, detected incidentally $(7,8)$. However, they can rarely cause severe symptoms such as abdominal pain, intestinal obstruction, invagination, life-threatening bleeding, diarrhoea or even perforation (9-23). Franc-Law et al. (15) reviewed 275 previously reported cases of colonic lipoma, 28 patients $(10 \%)$ had a dramatic presentation with pain and/or rectal bleeding, being the most significant prodromal symptom. In this subset the lipomas tended to be larger, frequently had associated marked necrosis or ulceration, and were less likely to be located in the ascending colon and caecum. Such lipomas usually reveal marked ischaemic changes (15).

\section{Diagnostics}

There are no difficulties to diagnose gastrointestinal lipomas properly in vast majority of cases. Endoscopic appearance of a lipoma is quite characteristic, with its bright yellow colour. The lesions are soft and compressible (a cushion sign), the overlying mucosa is normal (1). Recognition at endoscopic ultrasound, computed tomography or magnetic resonance imaging is unequivocal and definite, too.

Colour of infarcted lipomas is dark purple and brown-reddish (with tiny islands of yellowish adipose tissue). Their surface is smooth, glossy and tight (24). Quite seldom, it might be difficult to distinguish other mesenchymal tumours (like liposarcoma), especially in symptomatic elderly people. Surgical resection with subsequent histology may be the solution in such a case (25).

\section{Therapeutic options}

Asymptomatic lipomas do not require any treatment. Symptomatic gastrointestinal lipomas could be removed endoscopically by means of snare polypectomy $(5,6,17,18$, $23,26-30)$ or by endoscopic submucosal dissection (31-33). Preventive submucosal injection (saline or epinephrine), clipping of a lipoma base and the use of detachable nylon or polyglactin loop could reduce the risk of complications such as bleeding or perforation (28, 34-39). Some authors recommend the use of a double-channel endoscope with placing a ligating loop device around the lipoma base with the assistance of a grasping forceps (40) or grasping-forceps-assisted endoscopic resection (41-44). Endoscopic polypectomy is considered to be possible in smaller size (less than $3 \mathrm{~cm}$ ) and pedunculated lipomas $(13,45)$. Larger lipomas are suggested by some authors for surgery because of the risk of complications after endoscopic polypectomy of submucosal tumours (perforation, bleeding) $(8,13,15,45-48)$. Use of SB knife (a scissor type device for submucosal dissection) with double-balloon endoscopy has been reported as a safe option to avoid surgical resection of small intestinal lipoma (49). Large transmural lipoma should be always referred for surgery (22). Self-amputation of colonic lipoma is exceptional (50-52). Some authors recommend looping and ligating lipoma with the detachable snare without endoscopic resection ("Loop-and-let-go" or "Ligate-and-let-go" technique) $(32,33,37,40,53,54)$. This ligation produces an asymptomatic, slow mechanical transsection of the lipoma (54). The endoscopic ligation should not be attempted in the treatment of broad based or sessile colonic lipomas (55). In these circumstances, endoscopic or surgical resection may be appropriate (54).

Large colonic lipomas occlude the intestinal lumen thus making it difficult to snare the lesion. In such a case, another 


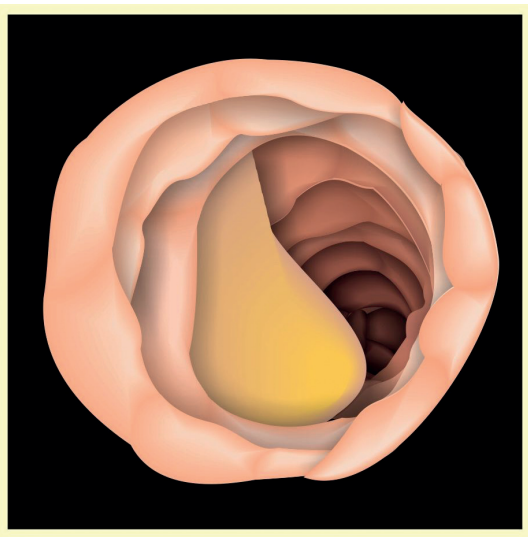

Fig. 1: Pedunculated lipoma of the large bowel. Bright yellow colour is characteristic.
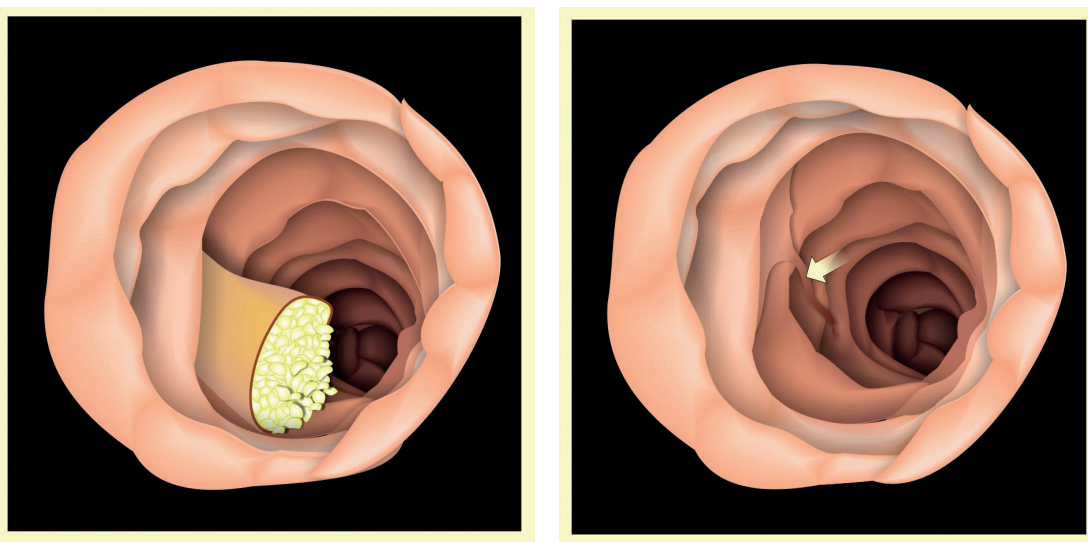

Fig. 2: Upper third of the lipoma body was cut off using a needle sphicterotome (a needle knife). option for giant lipomas is endoscopic treatment by means of unroofing technique (24) to avoid surgery.

\section{Unroofing technique}

Using the unroofing technique we cut off only the upper half or one third of the lipoma body using electrocautery snare. The remaining adipose tissue is subsequently extruded from the open surface. Therefore, this is a simple technique that allows both histological confirmation and complete treatment with minimal risk of perforation (see Figures No. 1-3). Using duodenoscope and grasp-and-snare technique in the management of a large, duodenal lipoma or combine this technique with a double-channel endoscope is also possible. Another possibility is consecutive dissecting the overlying mucosa on the lipoma body by means of a needle-knife in order to completely extrude the mass of the fat tissue (56-63).

We recommend this unroofing technique especially for giant and/or infarcted lipomas (54). We start with an initial cutting with an incision of the visible part of the polyp by means of a needle sphincterotome (needle knife). This transsection made it possible to subsequently grasp the lipoma by a snare and to cut off upper third of the tumour (24). Cut covering of lipoma should be extracted for histology.

Mimura et al. (56) were probably the first who reported this method by for endoscopic resection of colonic lymphangioma. Hizawa et al. (57) as the first used unroofing technique for the endoscopic resection of a large lipoma. They cut the upper third of large duodenal lipoma. This revealed a hole in the overlying mucosa and adipose material rapidly exuded from the cut surface through this opening (57). This technique only cuts off the upper half of the submucosal tumour, thus reducing the risk of complications. Since this initial experience, successful endoscopic treatment using unroofing technique has been reported by several authors $(29,31,34,58-60)$.
Binmoeller et al. (61) and Lee et al. (62) recommended endoscopic partial resection with the unroofing technique also for diagnostics of subepithelial tumours originating from the muscularis propria, such as gastrointestinal stromal tumours, leiomyoma or neuroendocrine carcinoma. Unlike unroofing technique of lipomas, procedural blood oozing was relatively common (9/16 cases; $56 \%$ ) but easily controlled by argon plasma coagulation (62). There are no reports on local recurrence of lipomas after their endoscopic treatment, no data on follow-up of these patients are given in available literature.

\section{Complications}

Complications of the method are very rare. Adipose tissue contains not enough water to facilitate conduction of electric current, which is why endoscopists apply higher electrical output for snare during procedure, causing thermal injury on the colon wall adjacent to the mass and increasing the likelihood of perforation (58). The unroofing technique prevents this complication. In cases of polypectomy, polyps larger than $1 \mathrm{~cm}$ in the right colon or larger than $2 \mathrm{~cm}$ in the left colon and multiple polyps carried an increased risk of bleeding and/or perforation (63-65). Generally, lipoma with a broad base or a large diameter has the risk for complication after endoscopic resection (58).

\section{Conclusions}

In conclusion, transsection by means of electrocautery snare and/or needle sphicterotome is an optional and effective technique for endoscopic treatment of giant symptomatic gastrointestinal lipomas. The cut cover of the lipoma is possible to remove for histopathology. Although the transformation to liposarcoma is extremely rare (described only as sporadic case reports in the literature), biopsy from large 
lipomas is recommended. Cutting the lipoma body (unroofing technique) allowed flow out of adipose tissue from the lipoma. This technique is quite safe as the risk of perforation and/or bleeding is unlikely.

\section{Acknowledgements}

The work was supported by the programme PRVOUK P37/08 from Charles University.

We are much grateful to Mrs. Hana Kotlandová who kindly sketched the figures.

\section{References}

1. Bures J, Rejchrt S, et al. Small Bowel Investigation \& Atlas of Enteroscopy. Praha: Grada Publishing, 2001

2. Castro EB, Stearns MW. Lipoma of the large intestine: a review of 45 cases. Dis Colon Rectum 1972; 15: 441-4.

3. El-Khalil T, Mourad FH, Uthman S. Sigmoid lipoma mimicking carcinoma: case report with review of diagnosis and management. Gastrointest Endosc 2000; 51 495-6.

4. Lyburn ID, Torreggiani WC, Thomson WH, Shepherd NA, Wallace D, Birch P. Giant lipoma of the descending colon. Hosp Med 2002; 63: 500-1.

5. Shapiro PD, Michas CA. Endoscopic removal of submucosal colonic lipomas. Arch Surg 1976; 111: 89

6. Sou S, Nomura H, Takaki Y, et al. Hemorrhagic duodenal lipoma managed by endoscopic resection. J Gastroenterol Hepatol 2006; 21(2): 479-81.

7. McGrew W, Dunn GD. Colonic lipomas: clinical significance and management South Med J 1985; 78: 877-9.

8. Pfeil SA, Weaver MG, Abdul-Karim FW, Yang P. Colonic lipomas: outcome of endoscopic removal. Gastrointest Endosc 1990; 36: 435-8.

9. Alkim C, Saşmaz N, Alkim H, Cağlikülekçi M, Turhan N. Sonographic findings in intussusception caused by a lipoma in the muscular layer of the colon. J Clin Ultrasound 2001; 29(5): 298-301.

10. Alponat A, Kok KY, Goh PM, Ngoi SS. Intermittent subacute intestinal obstruction due to a giant lipoma of the colon: a case report. Am Surg 1996; 62: 918-21.

11. Bahadursingh AM, Robbins PL, Longo WE. Giant submucocal sigmoid colon lipoma. Am J Surg 2003; 186: 81-2.

12. Buetow PC, Buck JL, Carr NJ, Pantongrag-Brown L, Ros PR, Cruess DF. Intussuscepted colonic lipomas: loss of fat attenuation on $\mathrm{CT}$ with pathologic correlation in 10 cases. Abdom Imaging 1996; 21(2): 153-6.

13. Chung YF, Ho YH, Nyam DC, Leong AF, Seow-Choen F. Management of colonic lipomas. Aust N Z J Surg 1998; 68: 133-5.

14. Felig DM. Bowel obstruction due to a large ileal lipoma. Gastrointest Endosc 2001; 53: 342

15. Franc-Law JM, Begin LR, Vasilevsky CA, Gordon PH. The dramatic presentation of colonic lipomata: report of two cases and review of the literature. Am Surg 2001; 67: 491-4.

16. Key JC, Roberts JW. Massive bleeding from colonic lipoma. Arch Surg 1980; 115: 889-90.

17. Lazaraki G, Tragiannidis D, Xirou P, Nakos A, Pilpilidis I, Katsos I. Endoscopic resection of giant lipoma mimicking colonic neoplasm initially presenting with massive haemorrhage: a case report. Cases J 2009; 2: 6462

18. Lee ES, Lee KN, Choi KS, et al. Endoscopic treatment of a symptomatic ileal lipoma with recurrent ileocolic intussusceptions by using cap-assisted colonoscopy. Clin Endosc 2013; 46(4): 414-17.

19. Miloudi N, Hefaiedh R, Khalfallah MT. Giant lipoma of the transverse colon causing colo-colonic intussusceptions. J Visc Surg 2012; 149(6): 421-2.

20. Rogy MA, Mirza D, Berlakovich G, Winkelbauer F, Rauhs R. Submucous large-bowel lipomas: presentation and management. An 18-year study. Eur J Surg 1991; 157(1): 51-5.

21. Taylor BA, Wolff BG. Colonic lipomas. Report of two unusual cases and review of the Mayo Clinic experience, 1976-1985. Dis Colon Rectum 1987; 30: 888-893.

22. Tsiaousidou A, Chatzitheoklitos E, Hatzis I, Alatsakis M, Katsourakis A. Giant transmural lipoma of the sigmoid colon. Hippokratia 2012; 16(3): 278-9.

23. Yu JP, Luo HS, Wang XZ. Endoscopic treatment of submucosal lesions of the gastrointestinal tract. Endoscopy 1992; 24: 190-3.

24. Bures J, Rejchrt S, Kopacova M. Transsection by means of needle sphincterotome followed by the unroofing technique for endoscopic therapy of a large colonic lipoma. Folia Gastroenterol Hepatol 2003; 1(1): 54-7.

25. Zhang H, Cong JC, Chen CS, Qiao L, Liu EQ. Submucous colon lipoma: a case report and review of the literature. World J Gastroenterol 2005; 11(20): 3167-9.
26. Araki $\mathrm{Y}$, Isomoto $\mathrm{H}$, Tsuji $\mathrm{Y}$, et al. Endoscopic removal with clipping for colonic ipomas. Kurume Med J 1998; 45(4): 341-3.

27. Creasy TS, Baker AR, Talbot IC, Veitch PS. Symptomatic submucosal lipoma of the large bowel. Br J Surg 1987; 74: 984-6.

28. Kim CY, Bandres D, Tio TL, Benjamin SB, Al-Kawas FH. Endoscopic removal of large colonic lipomas. Gastrointest Endosc 2002; 55(7): 929-31.

29. Kitamura K, Kitagawa S, Mori M, Haraguchi Y. Endoscopic correction of intussusception and removal of a colonic lipoma. Gastrointest Endosc 1990; 36: 509-11.

30. Stone C, Weber HC. Endoscopic removal of colonic lipomas. Am J Gastroenterol 2001; 96: 1295-7.

31. Lee KJ, Kim GH, Park do Y, et al. Endoscopic resection of gastrointestinal lipomas: a single-center experience. Surg Endosc 2014; 28(1): 185-92.

32. Matsushita M, Fukata N, Okazaki K. Endoscopic removal of large gastric lipomas: en bloc resection with submucosal dissection or partial resection with unroofing technique? Dig Endosc 2013; 25(2): 211-12.

33. Morimoto T, Fu KI, Konuma H, et al. Peeling a giant ileal lipoma with endoscopic unroofing and submucosal dissection. World J Gastroenterol 2010; 16(13): 1676-9.

34. Aydin HN, Bertin P, Singh K, Arregui M. Safe techniques for endoscopic resection of gastrointestinal lipomas. Surg Laparosc Endosc Percutan Tech 2011; 21(4): 218-222.

35. Kaltenbach T, Milkes D, Friedland S, Soetikno R. Safe endoscopic treatment of large colonic lipomas using endoscopic looping technique. Dig Liver Dis 2008; 40(12): 958-61.

36. Katsinelos P, Chatzimavroudis G, Zavos C, Paroutoglou G, Papaziogas B, Kountouras J. A novel technique for the treatment of a symptomatic giant colonic lipoma. J Laparoendosc Adv Surg Tech A 2007; 17(4): 467-9.

37. Lee IL, Tung SY, Lee KF, Chiu CT, Wu CS. Endoscopic resection of a large colonic leiomyoma. Chang Gung Med J 2002; 25(1): 39-44

38. Khorashad AK, Hosseini SM, Gaffarzadegan K, Farzanehfar MR, Zivarifar HR. Endoscopic resection of large colonic lipomas assisted by a prototype single-use endoloop device. J Res Med Sci 2011; 16(11): 1511-15.

39. Murray MA, Kwan V, Williams ST, Bourke MJ. Detachable nylon loop assisted removal of large clinically significant colonic lipomas. Gastrointest Endosc 2005; 61: 756-9.

40. Koo J, Kaffes A. Endoscopic resection of large colonic lipomas assisted by a prototype single-use Endoloop device. Endoscopy 2006; 38(6): 644-7.

41. Akahoshi K, Kojima H, Fujimaru T, et al. Grasping-forceps-assisted endoscopic resection of large pedunculated GI polypoid lesions. Gastrointest Endosc 1999; 50: 95-8.

42. Raju GS, Gomez G. Endoloop ligation of a large colonic lipoma: a novel technique. Gastrointest Endosc 2005; 62: 988-90.

43. Matsushita M, Takakuwa H, Matsubayashi Y, Kido M, Shimeno N, Okazaki $\mathrm{K}$. Handcrafted two-channel colonoscope for grasping-forceps-assisted resection of giant pedunculated polyps. Gastrointest Endosc 2005; 62: 132-6.

44. Matsushita M, Danbara N, Shimatani M, et al. Handcrafted two-channel colonoscope for removing large lipomas. Endoscopy 2006; 38: 644-7.

45. Bar-Meir S, Halla A, Baratz M: Endoscopic removal of colonic lipoma. Endoscopy 1981; 13: 135-6.

46. Grasso E, Guastella T. Giant submucosal lipoma cause colo-colonic intussusception. A case report and review of literature. Ann Ital Chir 2012; 83(6): 559-62.

47. Khawaja F. Pedunculated lipoma of the colon: risks of endoscopic removal. South Med J 1987; 80: 1176-9.

48. Nakagoe T, Sawai T, Tsuji T, et al. Minilaparotomy approach for removal of a large colonic lipoma: report of two cases. Surg Today 2004; 34(1): 72-5.

49. Toya Y, Endo M, Orikasa S, Sugai T, Matsumoto T. Lipoma of the small intestine treated with endoscopic resection. Clin J Gastroenterol 2014; 7(6): 502-5.

50. Jeong HK, Cho SB, Seo TJ, et al. Autoamputation of a giant colonic lipoma. Gut Liver 2011; 5(3): 380-2

51. Radhi JM. Lipoma of the colon: self amputation. Am J Gastroenterol 1993; 88: 1981-2.

52. Sidani SM, Tawil AN, Sidani MS. Extraction of a large self-amputated colonic lipoma: A case report. Int J Surg 2008; 6(5): 409-11.

53. Friedland S, Kahng LS, Torosis J, Soetkino RM. Ligate and let go. Gastrointest Endosc 2003, 58(3): 473-4.

54. Ivekovic H, Rustemovic N, Brkic T, Ostojic R, Monkemuller K. Endoscopic ligation ("Loop-And-Let-Go") is effective treatment for large colonic lipomas: a prospective validation study. BMC Gastroenterol 2014; 14: 122

55. Geraci G, Pisello F, Arnone E, Sciuto A, Modica G, Sciumè C. Endoscopic Resection of a Large Colonic Lipoma: Case Report and Review of Literature. Case Rep Gastroenterol 2010; 4(1): 6-11.

56. Mimura T, Kuramoto S, Hashimoto M, et al. Unroofing for lymphangioma of the large intestine: a new approach to endoscopic treatment. Gastrointest Endosc 1997; 46: 259-63

57. Hizawa K, Kawasaki M, Kouzuki T, Aoyagi K, Fujishima M. Unroofing technique for the endoscopic resection of a large duodenal lipoma. Gastrointest Endosc 1999; 49(3 Pt 1): 391-2

58. Kim GW, Kwon CI, Song SH, et al. Endoscopic resection of giant colonic lipoma: case series with partial resection. Clin Endosc 2013; 46(5): 586-90. 
59. Soares JB, Gonçalves R, Rolanda C. Endoscopic resection of a large colonic lipoma by unroofing technique. Endoscopy 2011; 43(Suppl 2) UCTN: E407.

60. Sugimoto K, Sato K, Maekawa H, et al. Unroofing technique for endoscopic resection of a large colonic lipoma. Case Rep Gastroenterol 2012; 6(2): 557-62.

61. Binmoeller KF, Shah JN, Bhat YM, Kane SD. Suck-ligate-unroof-biopsy by using a detachable 20-mm loop for the diagnosis and therapy of small subepithelial tumors (with video). Gastrointest Endosc 2014; 79(5): 750-5.

62. Lee CK, Chung IK, Lee SH, et al. Endoscopic partial resection with the unroofing technique for reliable tissue diagnosis of upper GI subepithelial tumors originating from the muscularis propria on EUS (with video). Gastrointest Endosc 2010; 71(1): 188-94.
63. Yong P, Bing-Yin Z, Tao W, Li-Jun T, Fu-Zhou T. Unroofing and grasp-and-snare techniques in the management of a large, duodenal lipoma by duodenoscope combined with a double-channel endoscope. Gastrointest Endosc 2014; 79(1): 27.

64. Heldwein W, Dollhopf M, Rösch T, et al. The Munich polypectomy study (MUPS): prospective analysis of complications and risk factors in 4000 colonic snare polypectomies. Endoscopy 2005; 37: 1116-22.

65. Geraci G, Pisello F, Arnone E, Sciuto A, Modica G, Sciumè C. Endoscopic Resection of a Large Colonic Lipoma: Case Report and Review of Literature. Case Rep Gastroenterol. 2010; 4(1): 6-11.

Received: $13 / 10 / 2015$

Corresponding author:

Accepted in revised form: $23 / 11 / 2015$

Professor Marcela Kopáčová, MD, PhD, 2nd Department of Medicine - Gastroenterology, University Hospital, Sokolská 581, 50005 Hradec Králové, Czech Republic; e-mail: marcela.kopacova@fnhk.cz 